\title{
CrimRxiv
}

\section{COVID-19 Exposes Need for Progressive Criminal Justice Reform}

Kathryn Nowotny, Zinzi Bailey, Marisa Omori, Lauren Brinkley-Rubinstein

Published on: Jul 01, 2020

DOI: 10.21428/cb6ab371.0505d932

License: Creative Commons Attribution 4.0 International License (CC-BY 4.0). 
